\title{
Enrichment of casing soil with Fe and soy-flour under Pseudomonas inoculation on yield and quality of button mushroom
}

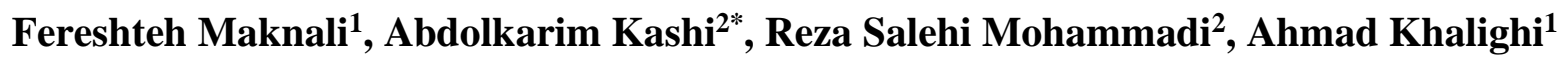 \\ ${ }^{1}$ Department of Horticultural Science, Science and Research Branch, Islamic Azad University, Tehran, Iran. E-mail: \\ maknaliifereshteh@gmail.com, khalighiahmad30@gmail.com
}

${ }^{2}$ Department of Horticultural Science, Faculty of Agricultural Science and Engineering, Campus of Agriculture and Natural Resources, University of Tehran, Karaj, Iran.E-mail: akkashi@ut.ac.ir, salehir@ut.ac.ir, * corresponding author

Received: 03/06/2020; Accepted: 02/01/2021.

\begin{abstract}
Effects of casing soil enrichment with soybean flour (SF) and iron (Fe) were explored on yield and quality of edible mushrooms inoculated with plant growth-promoting bacteria in a factorial experiment with four replications. $\mathrm{Fe}$ from Fe chelate source was applied at two levels of $0\left(\mathrm{Fe}_{0}\right)$ and $500 \mathrm{mg} \mathrm{L}^{-1}\left(\mathrm{Fe}_{500}\right)$, SF at three levels of $0 \%\left(\mathrm{SF}_{0}\right)$, $1.5 \%\left(\mathrm{SF}_{1.5}\right)$, and $3 \%\left(\mathrm{SF}_{3}\right)$ of compost dry weight, and bacteria inoculation at two levels (non-inoculation and inoculation of mycelia with $P$. putida). The maximum fresh yield $\left(20.3 \mathrm{~kg} \mathrm{~m}^{-2}\right)$, mushroom number (1041),

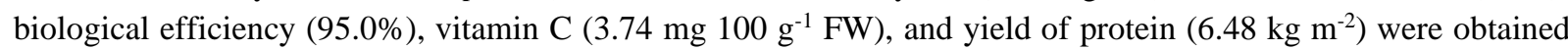
from $\mathrm{SF}_{1.5}+P$. putida. But, the maximum tryptophan $\left(1.37 \mathrm{mg} \mathrm{g}^{-1} \mathrm{DW}\right)$, methionine $\left(2.29 \mathrm{mg} \mathrm{g}^{-1} \mathrm{DW}\right)$, and antioxidant capacity $\left(4.25 \mathrm{mg} \mathrm{mL}^{-1}\right.$ ) were related to $\mathrm{SF}_{3}$ inoculated with $P$. putida. Furthermore, the maximum carbohydrate (5.64\%) was related to $\mathrm{Fe}_{500}+\mathrm{SF}_{3}$. Based on the results, casing soil enrichment with Fe did not have a significant influence on quantitative and qualitative traits of mushrooms, but SF application at the rate of $1.5 \%$, especially when accompanied by $P$. putida, played a more essential role. Thus, it is recommended to use $1.5 \% \mathrm{SF}$ along with $P$. putida to enhance the yield and qualitative traits of edible mushrooms.
\end{abstract}

Keywords: Antioxidant capacity, Casing soil, Fresh yield, Protein, Soy-flour..

\section{Enriquecimento do solo de cobertura com Fe farinha de soja sob inoculação de Pseudomonas no rendimento e qualidade do cogumelo}

\section{RESUMO}

Os efeitos do enriquecimento do solo de cobertura com farinha de soja (SF) e ferro (Fe) foram explorados no rendimento e na qualidade de cogumelos comestíveis inoculados com bactérias promotoras de crescimento de plantas em um experimento fatorial com quatro repetições. Fe da fonte de quelato de Fe foi aplicado em dois níveis de 0 (Fe0) e $500 \mathrm{mg} \mathrm{L}^{-1}$ (Fe500), SF em três níveis de 0\% (SF0), 1.5\% (SF1.5) e 3\% (SF3) de massa seca do composto e inoculação de bactérias em dois níveis (não inoculação e inoculação de micélios com P. putida). O rendimento fresco máximo $\left(20.3 \mathrm{~kg} \mathrm{~m}^{-2}\right)$, número de cogumelos (1041), eficiência biológica (95.0\%), vitamina $\mathrm{C}$ (3.74 mg $100 \mathrm{~g} \mathrm{~g}^{-1} \mathrm{FW}$ ) e rendimento de proteína $\left(6.48 \mathrm{~kg} \mathrm{~m}^{-2}\right)$ foram obtidos a partir de SF1.5 + P. putida. Porém, os valores máximos de triptofano $\left(1.37 \mathrm{mg} \mathrm{g}^{-1} \mathrm{DW}\right)$, metionina $\left(2.29 \mathrm{mg} \mathrm{g}^{-1} \mathrm{DW}\right)$ e capacidade antioxidante $(4.25$

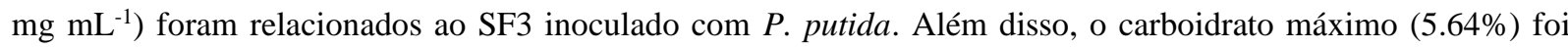
relacionado ao $\mathrm{Fe} 500+\mathrm{SF} 3$. Com base nos resultados, o enriquecimento do solo de cobertura com Fe não teve influência significativa nas características quantitativas e qualitativas dos cogumelos, mas a aplicação de SF na proporção de $1.5 \%$, principalmente quando acompanhada por P. putida, teve um papel mais essencial. Assim, é recomendado o uso de $1.5 \% \mathrm{SF}$ junto com $P$. putida para aumentar o rendimento e as características qualitativas dos cogumelos comestíveis.

Palavras-chave: Capacidade antioxidante, Solo de cobertura, Rendimento fresco, Proteína, Farinha de soja.. 


\section{Introduction}

Edible mushrooms are among the biggest and most valuable natural resources for protein-rich foodstuff production from low-value food in a short time so that they have a special place in the world (Chang and Wasser, 2017). Mushrooms grow on composts including straw, chicken manure, chalk, and other additives, which are costly inputs for mushroom production (Roise et al., 2016). So, mushroom producers look for methods to reduce their production costs by increasing bio-efficiency and more production from composts (Kim et al., 2008). To gain higher yields, the substrate should be enriched by adding such nutrients as nitrogen $(\mathrm{N})$, phosphorus $(\mathrm{P})$, potassium $(\mathrm{K})$, zinc $(\mathrm{Zn})$, and iron $(\mathrm{Fe})$. Although chicken manure that is incorporated into the compost contains these nutrients, it sometimes fails to supply all mushroom demands, so Desrumaux et al., (2000) emphasize the addition of $\mathrm{Fe}$ to the casing soil since $\mathrm{Fe}$ is the main component of catalase and cytochrome in $A$. bisporus required at a rate of $0.1-0.3 \mathrm{mg} \mathrm{kg}^{-1}$ (PardoGiménez et al., 2018). Research shows that individual micronutrients, e.g. copper $(\mathrm{Cu})$, boron $(\mathrm{B})$, and $\mathrm{Fe}$, added to the substrate at spawning do not influence the yield significantly (Weil et al., 2006). Nonetheless, it seems that micronutrient supplements provide mushroom producers with a potential opportunity to improve the efficiency and quality of freshly harvested mushrooms (Kumar et al., 2020).

Compost enrichment has drawn interest as a good way to increase crop yields. Enrichment is performed by using various supplements, perhaps with a plant origin or derived from compounds whose components are released gradually to feed the mycelia (Schisler, 1967; Delphina and Royse, 2016). Supplements are mostly applied to compost or spawn to allow complexes to take up them (Nurudeen et al., 2014; Sing and Jain, 2016; Carrasco et al., 2018). Research has identified cottonseed meal, peanut meal, wheat bran, and especially soy-flour to be the best supplements with plant origins (Sing and Jain, 2016). Soy-flour, which is derived from grounding dry soybeans, is an ideal protein-based supplement containing a high concentration of carbon (Zied et al., 2011).

The use of soy-flour as the main source of organic $\mathrm{N}$ in the substrate of Agaricus has been reportedly successful (Mascarin et al., 2018). According to Carrasco et al., (2018), soy-flour partly replaces chicken manure and is a good alternative to reduce the $\mathrm{C} / \mathrm{N}$ ratio and boost microbial activity in the $A$. bisporus substrate so that it not only increases the yield but is also good for enhancing mushroom protein content. Pardo-Giménez et al., (2018) report that soy-flour has a high protein content varying in the range of 40-50\% and performs as an excellent source of nitrogen and carbon, permitting better growth and fastest pinhead formation of fruit bodies.
By studying $\mathrm{N}$ concentrations of different soybean cultivars, Mascarin et al., (2018) found that the total $\mathrm{N}$ content of soybeans was in the range of 7.1-13.4\%, which is much higher than that of cottonseed and corn flour. Nurudeen et al., (2014) compared some nutrient supplements and revealed that soy-flour significantly outperformed corn flour, wheat flour, and cow bean flour in biological efficiency, fresh yield, and mushroom population.

To bolster edible mushroom yields, biofertilizers can greatly influence the profitability along with breeding techniques and supplement applications (Pratiksha et al., 2017). The most important microorganisms, applied in biofertilizer production, plant growth-promoting rhizobacteria (PGPRs) including Pseudomonas (Prathap and Ranjitha Kumari, 2015), which exists in the casing soil used in $A$. bisporus mushroom production and interacts with the mycelia of this species (Siyoum et al., 2015; Pratiksha et al., 2017).

The bacteria of the genus Pseudomonas are from the family Pseudomonadaceae, which are non-sporing, rodshaped or slightly curved, polar-flagellated, and Gramnegative. Among the species of Pseudomonas, $P$. putida is more effective than other species in the growth of white button mushroom mycelia (Mohammad and Sabaa, 2013; Chen et al., 2013). This bacterium plays a key role in the next growth stages of the mushroom including fruit-bearing (Colauto et al., 2016) and improves the yield, dry weight, and protein content of this mushroom (Zarenejad et al., 2012). P. putida has a positive role in its host as it produces indole-3-acetic acid (IAA), improves the solubility of mineral phosphate, reduces growth-inhibiting compounds e.g. ethylene, and secretes siderophore to cope with pathogens (Roca et al., 2013). These mechanisms of $P$. putida with the mycelia of edible mushrooms can be studied as they can enhance mushroom yields.

Research shows that IAA-producing bacteria increase fresh weight, dry weight, protein content, population per unit area, and cap diameter of A. bisporus (Mohammad and Sabaa, 2013). Chen et al., (2013) enumerate ethylene as a candidate inhibitor of the A. bisporus growth. They revealed that the $P$. putida strains contributed to the growth of the $A$. bisporus hyphae by producing the enzyme 1-aminocyclopropane-1-carboxylic acid (ACC) deaminase, reducing $\mathrm{ACC}$, and thereby reducing ethylene level, but the mutant bacteria that produced only slight amounts of ACC deaminase inhibited the growth of hyphae. Therefore, the $A$. bisporus and $P$. putida growth-inhibiting ethylene increase the growth of fungal mycelia by absorbing and consuming ethylene precursors. $P$. putida contributes to maintaining crop quality and increasing host yield by producing siderophores that control pathogenic microorganisms and facilitate Fe uptake (Gülser and Pekşen, 2003; Colauto et 
al., 2016). The application of Fe to the substrate of $A$. bisporus induces the formation of pinhead structures (Mohammad and Sabaa, 2013).

Since no report has ever been published on the effects of casing soil enrichment by the interaction of a micronutrient $(\mathrm{Fe})$ and an organic supplement (soybean flour) along with $P$. putida on the quantitative and qualitative traits of $A$. bisporus, the present research aims to shed light on the influence of casing soil enrichment with nutritional supplement and $P$. putida on improving the quantitative and qualitative traits of $A$. bisporus.

\section{Material and Methods}

The research was conducted at the Horticultural Research Department of Agricultural and Natural Resources Center of Ahvaz, Southern Iran (38 $21^{\prime}$ N., $48^{\circ} 50^{\prime}$ E., $23 \mathrm{~m}$. altitude from sea level) in 2019. It was a factorial experiment based on a completely randomized design replicated four times in which the treatments included casing soil enrichment with iron (as Fe-chelate at a rate of 0 or $500 \mathrm{mg} \mathrm{L}^{-1}$ ), soybean flour as the complementary casing soil (at a rate of $0,1.5$ or $3 \%$ of the wet weight of compost), and phase II compost inoculated/not inoculated with Pseudomonas putida strain R53W.

The soy-flour (40\% protein, $19 \%$ lipid, and $8 \%$ moisture) was supplied by Soyan Toos Company. The Fe chelate, which included $9 \% \mathrm{Fe}$, was procured from
Khazra Company, Iran. Also, mushroom spawn, casing soil, and compost were supplied by Qarch-Jolgeh-Dez Company. Tables 1 and 2 present the results of the physical and chemical analysis of the casing soil and compost.

The experiment was conducted by the shelf method as it has a high production efficiency and low space requirement. The first shelf was placed $15 \mathrm{~cm}$ above the ground and the shelves, which were $140 \mathrm{~cm}$ wide, were spaced by 65 . Also, to cultivate the mushroom, bag blocks were placed on the shelves. The blocks were polyethylene $140 \times 160 \mathrm{~cm}$ rectangular containing $17 \mathrm{~kg}$ compost. Each block was considered a single experimental plot.

Pseudomonas putida strain R156 was supplied by the microbial collections of Water and Soil Research Institute, Karaj. It is one of the best Pseudomonas strains and can produce siderophores used to solubilize organic and mineral phosphates and generate auxin and ACCdeaminase (Table 3 ). To prepare the $P$. putida inoculant, adequate amounts of the nutrient culture media containing cycloheximide were first prepared.

Then, a loop of the target bacteria was inoculated to the Erlenmeyer containing the sterile culture medium in sterile conditions and was placed in a shaker-equipped incubator at $150 \mathrm{rpm}$ at $28^{\circ} \mathrm{C}$. The counting of bacteria by the plate method showed that the population of the bacteria reached $10^{8}$ cells $\mathrm{mL}^{-1}$ in four days. Each $17-\mathrm{kg}$ substrate was added with $85 \mathrm{~mL}$ of the propagated bacterial suspension (Kim et al., 2008).

Table 1. The properties of the casing soil

\begin{tabular}{|c|c|c|c|c|c|c|c|c|c|c|c|c|}
\hline \multirow{2}{*}{$\begin{array}{l}\text { Moisture } \\
(\%)\end{array}$} & \multirow{2}{*}{$\begin{array}{l}\mathrm{EC} \\
\mathrm{dS} \mathrm{m}^{-1}\end{array}$} & \multirow{2}{*}{$\mathrm{pH}$} & \multirow{2}{*}{ S.P } & $\mathrm{OM}$ & $\mathrm{N}$ & $\mathrm{P}$ & $\mathrm{K}$ & \multirow{2}{*}{$\mathrm{C} / \mathrm{N}$} & $\mathrm{Cu}$ & $\mathrm{Fe}$ & $\mathrm{Mn}$ & $\mathrm{Zn}$ \\
\hline & & & & $(\%)$ & & & & & \multicolumn{4}{|c|}{$\left(\mathrm{mg} \mathrm{kg}{ }^{-1}\right)$} \\
\hline 25 & 2.1 & 5.25 & 10.0 & 20.1 & 1.35 & 0.19 & 0.13 & 8.5 & 10 & 3800 & 80 & 25 \\
\hline
\end{tabular}

EC: Electrical conductivity, S.P: Saturation percentage, OM: Organic matter, N: Nitrogen, P: Phosphorus, K: Potassium, C/N: Carbon/Nitrogen, $\mathrm{Cu}$ : Copper, Fe: Iron; Mn: Manganese; Zn: Zinc.

Table 2. The properties of the phase II compost

\begin{tabular}{|c|c|c|c|c|c|c|c|c|c|c|c|c|}
\hline \multirow{2}{*}{$\begin{array}{l}\text { Moisture } \\
(\%)\end{array}$} & \multirow{2}{*}{$\begin{array}{l}\mathrm{EC} \\
\mathrm{dS} \mathrm{m}^{-1}\end{array}$} & \multirow{2}{*}{$\mathrm{pH}$} & $\mathrm{OM}$ & OC & $\mathrm{N}$ & $\mathrm{P}$ & $\mathrm{K}$ & \multirow{2}{*}{$\mathrm{C} / \mathrm{N}$} & $\mathrm{Cu}$ & $\mathrm{Fe}$ & $\mathrm{Mn}$ & $\mathrm{Zn}$ \\
\hline & & & & $(\%)$ & & & & & \multicolumn{4}{|c|}{$\left(\mathrm{mg} \mathrm{kg}^{-1}\right)$} \\
\hline 73.6 & 7.7 & 7.63 & 44.1 & 26.3 & 1.95 & 2.65 & 3.35 & 13.4 & 48 & 190 & 330 & 195 \\
\hline
\end{tabular}

EC: Electrical conductivity, S.P: Saturation percentage, OM: Organic matter, N: Nitrogen, P: Phosphorus, K: Potassium, C/N: Carbon/Nitrogen, Cu: Copper, Fe: Iron; Mn: Manganese; Zn: Zinc.

Table 3. The properties of P. putida used in the present study

\begin{tabular}{ccccc}
\hline $\begin{array}{c}\text { Pseudomonas } \\
\text { strain }\end{array}$ & $\begin{array}{c}\text { Phosphate } \\
\text { solubilizing }\end{array}$ & $\begin{array}{c}\text { ACC-deaminase } \\
\text { production }\end{array}$ & $\begin{array}{c}\text { IAA production } \\
\left(\mathrm{mg} \mathrm{L}^{-1}\right)\end{array}$ & $\begin{array}{c}\text { Siderophore production } \\
\text { (halo diameter/colony diameter) }\end{array}$ \\
\hline P. Putida strain R156 & & & 9.8 & 1.9
\end{tabular}

P. Putida strain R156

$+$

$+$

9.8

1.9

ACC: 1-aminocyclopropane-1-carboxylic acid; IAA: Indole-3-acetic acid 
Before spawning, all casing soil supplement treatments were sterilized in an autoclave $\left(121^{\circ} \mathrm{C}, 34.1\right.$ lb) for 15 minutes. The spawning of $A$. bisporus was performed at a rate of $5 \mathrm{~g} \mathrm{~kg}^{-1}$ compost by layered seeding. Then, the substrates were inoculated with $P$. putida except for the non-inoculated treatment which was left without any bacteria (Kim et al., 2008). At the next step, the casing soil treated with either Fe chelate, soybean flour, or none (the control) was applied uniformly to form a 4-cm thickness layer and the ruffling operation was performed. At this moment, the compost was $25^{\circ} \mathrm{C}$ with $\mathrm{pH} 7.5$ and $70 \%$ moisture and the casing soil had pH 7.4 with $73 \%$ moisture. After spawning, they were kept in a growth chamber at a relative humidity of $90 \pm 5 \%$, a temperature of $24 \pm 1^{\circ} \mathrm{C}$, and $\mathrm{CO}_{2}$ content of 5000-6000 ppm in darkness until pinhead parts emerged (Remezan and Siah Sar, 2010). After two weeks, when mycelia grew inside the casing soil, the aeration (shocking) operation was performed at a humidity of $85 \pm 5 \%, \mathrm{CO}_{2}$ content of 800-1000 ppm, and a temperature of $17 \pm 1^{\circ} \mathrm{C}$ (Remezan and Siah Sar, 2010). Ruffles and temperature drop imposed a shock to trigger the reproductive phase. All mushroom-specific operations including irrigation were uniformly applied to all treatments.

At the end of the culture period, mushrooms were harvested before full maturity. So, $1 \mathrm{~m}^{2}$ was harvested from each plot to measure the traits described below. The picked mushrooms were placed in paper pockets and their fresh weight was measured with a digital $0.01-\mathrm{g}$ scale to record it as the fresh yield. Among the picked mushrooms, 20 were selected randomly to measure their height and cap diameter with a tape measure (Mamiro and Royse, 2008). Then, to determine their dry weight, the mushrooms were cut into thin layers and oven-dried at $70^{\circ} \mathrm{C}$ for 24 hours.

To find out ash content, $5 \mathrm{~g}$ of mushroom dry matter was weighed precisely and was placed in Chinese crucibles inside an electrical furnace at $550^{\circ} \mathrm{C}$. After 8 hours, they were weighed. The following equation was used to estimate ash content (Vieyra, 2009):

Ash content $(\%)=\frac{\text { Ash weight of mushrooms }(\mathrm{g})}{\text { Dry matter weight of mushrooms }(\mathrm{g})} \times 100$

Dry matter (DM) content and biological efficiency (BE) of the mushrooms were calculated by the following equations (Kirbag and Akyuz, 2009):

$$
\begin{aligned}
& \operatorname{DM}(\%)=\frac{\text { Dry weight of mushrooms }(\mathrm{g})}{\text { Fresh weight of mushrooms }(\mathrm{g})} \times 100 \\
& \mathrm{BE}(\%)=\frac{\text { Fresh weight of mushrooms }(\mathrm{g})}{\text { Total substrates used }(\mathrm{g})} \times 100
\end{aligned}
$$

To measure the protein content of the mushrooms, nitrogen $(\mathrm{N})$ content was first measured by the Kjeldahl method and then, protein content was estimated by the following equation (Han, 1999):

$$
\text { Protein content }(\%)=\mathrm{N} \times 4.38
$$

Vitamin C was determined according to the method of Klein and Perry (1982). Mushroom mycelia (1 g) was extracted with $10 \mathrm{ml}$ of $1 \%$ metaphosphoric acid for 45 minutes and filtered through a Whatman filter paper No. 1. The filtrate $(1 \mathrm{ml})$ was mixed with $9 \mathrm{ml}$ of 2,6 dichloroindophenol and the absorbance was measured at $515 \mathrm{~nm}$.

The anti-oxidant capacity in mushroom samples was determined by measuring the decrease in absorbance at $517 \mathrm{~nm}$ by a UV-vis spectrophotometer (Model 5384, Agilent Technologies) due to the DPPH (2,2-diphenyl-1picrylhydrazyl) radical reduction, indicating the antioxidant activity of the compounds in a short time. It was obtained from the following equation (SanchezMoreno et al., 1998):

Free radical scavenging activity $=\frac{(A c-A s)}{A c} \times 100$

where $A c$ is the absorbance of $100 \mu \mathrm{M}$ methanolic DPPH only and $A s$ is the absorbance of the reaction mixture.

The lysine, methionine, and tryptophan contents were analyzed according to the method of Bosch et al., (2006) with some modifications. Mushroom powders ( $1 \mathrm{~g}$ ) were shaken with $50 \mathrm{ml}$ of $0.1 \mathrm{~N}$ hydrochloric acid $(\mathrm{HCl})$ solution for 60 minutes and filtered. The purified filtrate was mixed with OPA (o-phthalaldehyde reagent), shaken to facilitate derivatization. Then, it was immediately injected onto the HPLC for assessment (Waters Alliance 2695). Each of the amino acids was quantified by the curve of the authentic amino acid.

All data were subjected to the analysis of variance (ANOVA) using SAS software (SAS Institute, Cary, NC, USA V9.4) Software. In case the $F$ test indicated statistical significance at $\mathrm{P}<0.01$ or $\mathrm{P}<0.05$, the least significant difference (LSD) was used to separate the means.

\section{Results and Discussion}

Mushroom number and yield were influenced by the interaction effect of $\mathrm{SF} \times \mathrm{Fe} \times \mathrm{B}($ Table 4$)$. When no Fe was applied $\left(\mathrm{Fe}_{0}\right)$, the highest mushroom number was obtained from $\mathrm{SF}_{1} \times \mathrm{B}_{1}$, but under the application of $\mathrm{Fe}$ $\left(\mathrm{Fe}_{500}\right)$, no significant dif ference was observed between $\mathrm{SF}_{1} \times \mathrm{B}_{1}$ and $\mathrm{SF}_{2} \times \mathrm{B}_{1}$. Similarly, the non-inoculated mushrooms did not show a significant difference between $\mathrm{SF}_{1.5}$ and $\mathrm{SF}_{3}$, but these two treatments had more mushrooms than $\mathrm{SF}_{0}$. Mushroom fresh yield responded 
to the treatments just like how mushroom number did so that the maximum yield was obtained from the treatments that produced the most number of mushrooms. The application of soybean flour, especially $\mathrm{SF}_{1.5}$, to the substrates treated with $\mathrm{Fe}_{500}$ and Pseudomonas was related to a higher yield than the substrates just treated with Pseudomonas.

The increase in mushroom number and yield by increasing the application of soybean flour up to $0.5 \mathrm{~kg} \mathrm{~m}^{-}$ ${ }^{2}$ was also reported by Zied et al., (2011). They observed that when soybean powder was applied in excess to the mushroom need, the yield was decreased and the mushroom quality was lost sharply (Table 5). Jiang et al., (2011) and Carrasco et al., (2018) ascribed the effect of soybean powder overuse on yield loss to the rise of temperature immediately after the application of soybean powder resulting from the severe metabolic and enzymatic activity of the mushrooms.
We observed that when $\mathrm{SF}_{3}$ was applied without bacteria, it reduced yield, but when it was accompanied with $P$. putida, no significant difference occurred with $\mathrm{SF}_{1.5}$ because bacteria consume $\mathrm{N}$ content of soybean powder, thereby making it unavailable to the mushrooms and providing them with the nutrients with delay. Similar to our findings,

Mohammad and Sabaa (2013) found that supplements can be made more efficient by inducing a delay in their availability versus their immediate availability. They demonstrated the positive role of $P$. putida and Rhodopseudomonas palustris in impeding the availability of nutrients. Kim et al., (2008) employed Pseudomonas strain P7014 and observed that the growth of mushroom mycelia was increased by 1.6 folds. Also, primordia were formed earlier and the total number of days for mushroom growth was decreased versus their non-inoculated counterparts

Table 4. Analysis of variance for the effects of Fe, bacteria and soy-flour on mushroom number, fresh yield, biological efficiency, dry matter ratio, ash content, protein content and protein yield

\begin{tabular}{lllllllll}
\hline \multirow{2}{*}{ S.O.V } & \multirow{2}{*}{ df } & \multicolumn{9}{l}{ Mean square (MS) } \\
\cline { 3 - 8 } & & Mushroom & Mushroom & Biological & Dry matter & Ash & Protein & Protein \\
\hline Replication & 3 & $50634^{* *}$ & $0.036 \mathrm{~ns}$ & $0.004 \mathrm{~ns}$ & $0.395 \mathrm{~ns}$ & $3.09 \mathrm{~ns}$ & $30.5 \mathrm{~ns}$ & $1.43^{*}$ \\
Iron (Fe) & 1 & $6509187^{* *}$ & $0.185^{* *}$ & $1208^{* *}$ & $2.62^{* *}$ & $1.072 \mathrm{~ns}$ & $0.634 \mathrm{~ns}$ & $0.028 \mathrm{~ns}$ \\
Pseudomona (B) & 1 & $263835^{* *}$ & $134^{* *}$ & $2935^{* *}$ & $0.189 \mathrm{~ns}$ & $4.38^{*}$ & $58.0^{* *}$ & $19.6^{* *}$ \\
Soy-flour (SF) & 2 & $56961^{* *}$ & $20.4^{* *}$ & $445^{* *}$ & $0.6718^{* *}$ & $19.3^{* *}$ & $294^{* *}$ & $12.1^{* *}$ \\
$\mathrm{Fe} \times \mathrm{B}$ & 1 & $92.5 \mathrm{~ns}$ & $23.4^{* *}$ & $513^{* *}$ & $1.989^{* *}$ & $1.78 \mathrm{~ns}$ & $345^{* *}$ & $5.11^{* *}$ \\
$\mathrm{SF} \times \mathrm{Fe}$ & 2 & $53905^{* *}$ & $3.67^{* *}$ & $78.6^{* *}$ & $0.117 \mathrm{~ns}$ & $0.465 \mathrm{~ns}$ & $265^{* *}$ & $7.19^{* *}$ \\
$\mathrm{SF} \times \mathrm{B}$ & 2 & $11705 \mathrm{~ns}$ & $1.41^{* *}$ & $27.1^{* *}$ & $1.822^{* *}$ & $0.708 \mathrm{~ns}$ & $21.7 \mathrm{~ns}$ & $1.32 \mathrm{~ns}$ \\
$\mathrm{SF} \times \mathrm{Fe} \times \mathrm{B}$ & 2 & $46628^{* *}$ & $2.99^{* *}$ & $69.6^{* *}$ & $2.247^{* *}$ & $0.831^{* *}$ & $87.6^{* *}$ & $4.93^{* *}$ \\
Error & 33 & 5486 & 0.028 & 0.599 & 0.185 & 0.943 & 14.2 & 0.469 \\
\hline $\mathrm{CV}(\%)$ & & 6.510 & 6.92 & 11.9 & 8.280 & 6.620 & 13.4 & 13.7 \\
\hline
\end{tabular}

** $P<0.01, * P<0.05$, ns not significant.

Table 5. Means comparison for the interactive effect of $\mathrm{Fe} \times$ bacteria $\times$ soy-flour on mushroom number, fresh yield, biological efficiency, dry matter ratio, protein content, and protein yield

\begin{tabular}{|c|c|c|c|c|c|c|c|c|}
\hline $\mathrm{Fe}$ & B & $\mathrm{SF}$ & $\begin{array}{l}\text { Mushroom } \\
\text { number } \mathrm{m}^{2}\end{array}$ & $\begin{array}{l}\text { Mushroom yield } \\
\left(\mathrm{kg} \mathrm{m}-^{2}\right)\end{array}$ & $\begin{array}{l}\text { Biological } \\
\text { efficiency }(\%)\end{array}$ & $\begin{array}{l}\text { Dry matter } \\
\text { ratio }(\%)\end{array}$ & $\begin{array}{l}\text { Protein content } \\
(\%)\end{array}$ & $\begin{array}{l}\text { Protein Yield } \\
\left(\mathrm{kg} \mathrm{m}^{-2}\right)\end{array}$ \\
\hline \multirow{6}{*}{$\mathrm{Fe}_{0}$} & \multirow{3}{*}{$\mathrm{B}_{1}$} & $\mathrm{SF}_{0}$ & $807 c$ & $17.03 \mathrm{c}$ & $84.50 \mathrm{~b}$ & $5.38 \mathrm{ab}$ & $23.52 \mathrm{c}$ & $4.267 \mathrm{c}$ \\
\hline & & $\mathrm{SF}_{1.5}$ & $1041 \mathrm{a}$ & $20.36 \mathrm{a}$ & $95.06 \mathrm{a}$ & $5.46 a$ & $34.18 \mathrm{a}$ & $6.486 a$ \\
\hline & & $\mathrm{SF}_{3}$ & $904 b$ & $18.03 \mathrm{~b}$ & $84.03 b$ & $4.79 b c$ & $34.93 \mathrm{a}$ & $6.245 \mathrm{a}$ \\
\hline & \multirow{3}{*}{$\mathrm{B}_{0}$} & $\mathrm{SF}_{0}$ (control) & $796 c$ & $17.09 \mathrm{c}$ & $69.56 \mathrm{~d}$ & $5.04 \mathrm{abc}$ & $19.83 d$ & $3.393 d$ \\
\hline & & $\mathrm{SF}_{1.5}$ & $891 b$ & $18.00 \mathrm{~b}$ & $86.02 b$ & $4.493 c$ & $24.01 \mathrm{c}$ & $4.422 \mathrm{c}$ \\
\hline & & $\mathrm{SF}_{3}$ & $844 b$ & $18.10 \mathrm{~b}$ & $79.80 \mathrm{c}$ & $5.04 \mathrm{abc}$ & $30.66 \mathrm{~b}$ & $5.216 \mathrm{~b}$ \\
\hline \multirow{6}{*}{$\mathrm{Fe}_{500}$} & \multirow{3}{*}{$\mathrm{B}_{1}$} & $\mathrm{SF}_{0}$ & $826 a b$ & $16.073 b$ & $70.36 b$ & $5.428 \mathrm{a}-\mathrm{c}$ & $26.20 \mathrm{ab}$ & $4.921 \mathrm{abc}$ \\
\hline & & $\mathrm{SF}_{1.5}$ & $836 a$ & $20.181 \mathrm{a}$ & $87.14 \mathrm{a}$ & $5.235 \mathrm{bc}$ & $24.08 b$ & $4.874 \mathrm{abc}$ \\
\hline & & $\mathrm{SF}_{3}$ & $862 a$ & $20.178 \mathrm{a}$ & $87.13 \mathrm{a}$ & $5.102 \mathrm{c}$ & $28.15 \mathrm{ab}$ & $5.701 \mathrm{a}$ \\
\hline & \multirow{3}{*}{$\mathrm{B}_{0}$} & $\mathrm{SF}_{0}$ & $711 b$ & $16.587 b$ & $67.96 \mathrm{~b}$ & $5.534 \mathrm{ab}$ & $27.5 \mathrm{ab}$ & $4.630 \mathrm{bc}$ \\
\hline & & $\mathrm{SF}_{1.5}$ & $751 \mathrm{ab}$ & $17.354 b$ & $71.33 b$ & $5.176 b c$ & $31.190 \mathrm{a}$ & $5.425 \mathrm{ab}$ \\
\hline & & $\mathrm{SF}_{3}$ & $761 \mathrm{ab}$ & $19.150 \mathrm{a}$ & $73.91 b$ & $5.618 \mathrm{a}$ & $26.13 b$ & $4.184 c$ \\
\hline
\end{tabular}

$\mathrm{B}_{0}$ : inoculation, $\mathrm{B}_{1}$ : non- inoculation;

$\mathrm{Fe}_{0}$ : non-use of $\mathrm{Fe}, \mathrm{Fe}_{500}$ : use of $500 \mathrm{mg} \mathrm{Fe} \mathrm{L}^{-1}$;

$\mathrm{SF}_{0}, \mathrm{SF}_{1.5}$ and $\mathrm{SF}_{3}$ : use of soy-flour as $0,1.5 \%$ and $3 \%$ proportion of compost dry weight, respectively. 
Furthermore, inoculation with this bacteria increased mushroom weight and accelerated tillering and primordia formation. In a study on the use of non-sulfur bacteria, Vieira and Pecchia (2018) showed that the application of $5000 \mathrm{~mL}$ of suspension containing $3.3 \times 10^{9}$ viable cells $\mathrm{mL}^{-1}$ on each block increased mushroom yield by $39.53 \%$, but mushroom DM and protein content did not differ from the control significantly. The highest concentration of this bacteria suspension exhibited the highest mushroom yield of $14.33 \mathrm{~kg} \mathrm{~m}^{-2}$

About biological efficiency, ANOVA showed that the interaction effect of $\mathrm{SF} \times \mathrm{Fe} \times \mathrm{B}$ was significant for biological efficiency (Table 4). The application of soybean flour to the non-inoculated plots that were not treated with $\mathrm{Fe}$ increased this trait by $8.4 \%$ for $\mathrm{SF}_{1.5}$ and $0.63 \%$ for $\mathrm{SF}_{3}$ when compared to $\mathrm{SF}_{0}$ (the control), but inoculation with Pseudomonas in the absence of $\mathrm{Fe}$ increased biological efficiency by $19.6 \%$ and $5.9 \%$ in the treatments of $\mathrm{SF}_{1.5}$ and $\mathrm{SF}_{3}$ versus $\mathrm{SF}_{0}$, respectively. $\mathrm{Fe}$ application in the absence of Pseudomonas lessened the impact of soybean flour so that there was not a significant difference between different levels of SF.

But, when it was applied in the presence of Pseudomonas, although the two levels of $\mathrm{SF}_{1.5}$ and $\mathrm{SF}_{3}$ did not differ significantly, their biological efficiency was significantly higher than that of $\mathrm{SF}_{0}$ by $9.7 \%$. Overall, the highest biological efficiency was obtained from the treatment of $\mathrm{Fe}_{0}+\mathrm{B}_{1}+\mathrm{S}_{1.5}$ (Table 5). The results indicate that $\mathrm{Fe}$ application decreases biological efficiency, which was ascribed to its impact on reducing the activity of substrate bacteria by Carrasco et al., (2019) who found that higher rates of Fe decreased the synthesis of organic acids by bacteria on the one hand and reduced bacteria-host symbiosis on the other.

Thus, the decreased impact of soybean flour in the absence of Pseudomonas may be related to the retardation of soybean flour decomposition. However, by the activities it has in the rhizosphere Pseudomonas application contributes to the decomposition of soybean flour and makes it available to mushrooms gradually. This finding is consistent with the report of Colauto et al., (2016).

Dry matter percentage was affected by the interaction effect of $\mathrm{SF} \times \mathrm{Fe} \times \mathrm{P}($ Table 4$)$. In substrates not treated with $\mathrm{Fe}\left(\mathrm{Fe}_{0}\right)$, the highest dry matter percentage was obtained from $\mathrm{SF}_{1.5}$ inoculated with Pseudomonas $\left(\mathrm{B}_{1}+\right.$ $\mathrm{SF}_{1.5}$ ) although it did not differ from some other treatments significantly. However, it increased dry matter percentage by $7.41 \%$ versus the treatment of $\mathrm{B}_{0}+\mathrm{SF}_{0}$. In Fe-treated casing soils $\left(\mathrm{Fe}_{500}\right)$, the highest dry matter percentage was observed in the treatment of $\mathrm{B}_{0}+\mathrm{SF}_{3}$ whose dry matter percentage was $11.9 \%$ higher than that of the control (Table 5). Ash content was influenced by the main effects of Pseudomonas and soybean flour as well (Table 4).
The inoculated treatment had $8.46 \%$ higher ash content than the non-inoculated treatment (Figure 1).. Among the soy-flour levels, $\mathrm{SF}_{1.5}$ increased ash content by $11.2 \%$ versus $\mathrm{SF}_{0}$ significantly, but $\mathrm{SF}_{3}$ did not differ from $\mathrm{SF}_{0}$ significantly (Figure 2). Kertesz and Thai (2018), who studied some bacterial and fungal strains, reported that the growth of Agaricus and Pleurotus fungal species can mostly be induced by the bacteria from the genera Bacillus, Pseudomonas, and Bradyrhizobium.

During the growth of the mushrooms, these microorganisms are active in soil, substrate, casing soil, or host and improve yield, shorten production period, and enhance dry matter percentage. An increase in dry matter results in an increase in ash content, and improving the growth conditions for mushrooms facilitates the availability of nutrients, especially $\mathrm{N}$, thereby increasing dry matter (Vos et al., 2017). The higher dry matter and ash contents of mushrooms following the application of soybean flour and P. putida was attributed by Mohammad and Sabaa (2013) to the increased uptake of phosphates (P), $\mathrm{N}$ adjustment potential, and the ability to promote mycelium growth.

According to the results of ANOVA, the interaction effect of $\mathrm{SF} \times \mathrm{Fe} \times \mathrm{B}$ was significant for protein content and yield (Table 4 ). The comparison of means revealed that the maximum mushroom protein content was obtained from the soil treated with $\mathrm{B}_{1}+\mathrm{SF}_{3}$ but not enriched with $\mathrm{Fe}$, whereas, among the Fe-enriched soils, the one treated with $\mathrm{B}_{0}+\mathrm{SF}_{1.5}$ exhibited the highest protein content although its protein content was $9.3 \%$ lower than that of $\mathrm{B}_{1}$ $+\mathrm{SF}_{3}$.

Among both Fe-enriched and non-enriched soils, the highest protein yield was related to the treatment of $\mathrm{B}_{1}+$ $\mathrm{SF}_{3}$. However, there was not a significant difference between $\mathrm{B}_{1}+\mathrm{SF}_{3}$ and $\mathrm{B}_{1}+\mathrm{SF}_{1.5}$ when they were applied to non-enriched soil. The application of $\mathrm{Fe}_{500}$ alone $\left(\mathrm{Fe}_{500}\right.$ $\left.+\mathrm{B}_{0}+\mathrm{SF}_{0}\right)$ or in combination with $P$. putida $\left(\mathrm{Fe}_{500}+\mathrm{B}_{1}+\right.$ $\mathrm{SF}_{0}$ ) increased protein content by $29.5 \%$ and $23.1 \%$ versus the control $\left(\mathrm{Fe}_{0}+\mathrm{B}_{0}+\mathrm{SF}_{0}\right.$; Table 5). So, it can be said that soybean flour and Pseudomonas have a positive relationship with protein content, but $\mathrm{Fe}$ has a negative relationship with it. Although there are reports as to the positive impact of $\mathrm{Fe}$ on protein and yield of mushrooms, some have also reported its negative relationship with some supplements including wheat bran and cottonseed powder.

Carrasco et al., (2018) concluded that there was a positive significant relationship between protein content and amino acids, which is in agreement with our findings as to the effect of P. putida and soybean powder on the content of protein and amino acids. Methionine and tryptophan contents were influenced by the interaction effect of $\mathrm{SF} \times \mathrm{B}$, but lysine was impacted only by the main effects of B and FS significantly (Table 6). 
Table 6. Analysis of variance of Fe, bacteria and soy-flour effects on content of vitamin c, carbohydrate, tryptophan, lysine, methionine and antioxidant capacity of mushroom

\begin{tabular}{llllllll}
\hline \multirow{2}{*}{ S.O.V } & \multirow{2}{*}{ df } & \multicolumn{7}{c}{ Mean square (MS) } \\
\cline { 3 - 8 } & & Methionine & Lysine & Tryptophan & Carbohydrate content & Vitamin C & Anti-oxidant capacity \\
\hline Replication & 3 & $6.40^{* *}$ & $0.022 \mathrm{~ns}$ & $1.31^{* *}$ & $718^{* *}$ & $12.3^{* *}$ & $9.89^{* *}$ \\
Iron (Fe) & 1 & $0.012 \mathrm{~ns}$ & $1.671 \mathrm{~ns}$ & $0.309 \mathrm{~ns}$ & $30.1 \mathrm{~ns}$ & $0.047 \mathrm{~ns}$ & $0.039 \mathrm{~ns}$ \\
Pseudomonas(B) & 1 & $1.79^{* *}$ & $4.161^{* *}$ & $1.30^{* *}$ & $57.6^{* *}$ & $3.35^{* *}$ & $18.5^{* *}$ \\
Soy-flour (SF) & 2 & $3.09^{* *}$ & $6.67^{* *}$ & $1.732^{* *}$ & $294^{* *}$ & $0.297^{*}$ & $0.018 \mathrm{~ns}$ \\
Fe $\times$ B & 1 & $0.129 \mathrm{~ns}$ & $0.135 \mathrm{~ns}$ & $0.178 \mathrm{~ns}$ & $346^{* *}$ & $0.211 \mathrm{~ns}$ & $4.19^{* *}$ \\
SF $\times$ Fe & 2 & $0.032 \mathrm{~ns}$ & $0.093 \mathrm{~ns}$ & $0.228 \mathrm{~ns}$ & $265^{* *}$ & $0.055 \mathrm{~ns}$ & $0.030 \mathrm{~ns}$ \\
SF $\times$ B & 2 & $0.142^{*}$ & $0.089 \mathrm{~ns}$ & $0.718^{* *}$ & $21.7 \mathrm{~ns}$ & $0.367^{*}$ & $0.347 \mathrm{~ns}$ \\
SF $\times$ Fe $\times$ B & 2 & $0.005 \mathrm{~ns}$ & $0.016 \mathrm{~ns}$ & $0.109 \mathrm{~ns}$ & $7.6 \mathrm{~ns}$ & $0.0084 \mathrm{~ns}$ & $0.594 \mathrm{~ns}$ \\
Error & 33 & 0.044 & 0.282 & 0.130 & 13.27 & 0.091 & 0.223 \\
\hline CV $(\%)$ & & 10.9 & 11.5 & 37.1 & 5.18 & 8.52 & 13.6 \\
\hline
\end{tabular}

** $P<0.01, * P<0.05$, ns not significant.

Vieira and Pecchia (2018) ascribed the effect of Pseudomonas on increasing the mushroom protein content to the enhancement of substrate quality by shortening the composting process, facilitating the lignocellulose degradation, and the synergistic effect on mycelium growth by the release of nutrients.

Under both inoculation $\left(\mathrm{B}_{1}\right)$ and non-inoculation $\left(\mathrm{B}_{0}\right)$ conditions, $\mathrm{SF}_{3}$ was related to the highest amounts of methionine and tryptophan although, under noninoculation conditions, no statistically significant difference was observed between $\mathrm{SF}_{1.5}$ and $\mathrm{SF}_{3}$ so that under inoculation conditions, $\mathrm{SF}_{3}$ exhibited $23.5 \%$ higher methionine content than $\mathrm{SF}_{1.5}$ whereas it was $9.02 \%$ under non-inoculation conditions. This increase in tryptophan content was $34.1 \%$ under non-inoculation conditions and $15.7 \%$ under inoculation conditions (Figures 3 and 4).

Lysine was also $11.8 \%$ higher in mushrooms obtained from inoculation with $P$. putida than in those with no inoculation background (Figure 5). The application of soybean flour increased lysine content significantly as well so that $\mathrm{SF}_{1.5}$ and $\mathrm{SF}_{3}$ increased this trait by $11.8 \%$ and $20.5 \%$ versus $\mathrm{SF}_{0}$ (Figure 6). The application of protein-containing supplements during spawning has a well-proven role in increasing amino acids of mushrooms (Kertesz and Thai, 2018). According to Colak et al., (2007), lysine and methionine were decreased by as high as $49.1 \%$ in substrates with lower $\mathrm{N}$ content and the application of Pseudomonas to these substrates can further aggravate this decrease to $77.3 \%$.

Colauto et al., (2016) state that the increased activity of bacteria in media with a high $\mathrm{C} / \mathrm{N}$ ratio makes $\mathrm{N}$ unavailable to mycelia and not only impede harvest but also impairs fresh mushroom yield and quality. On the other hand, Chang and Wasser (2017) and Vieira and Pecchia (2018) argue that a low $\mathrm{C} / \mathrm{N}$ ratio in mushroom substrate increases its temperature and disturbs microbial activity and mycelium growth. Wang et al., (2000) and Bonati et al., (2004) have found that substrate
$\mathrm{N}$ affect mushroom protein content so that mushrooms with a higher protein content can be derived from substrates with a higher $\mathrm{N}$ content. Sing and Jain (2016) state that mushrooms may have high contents of minerals that exist in their growth media. Thus, the response of mushrooms to $\mathrm{Fe}$ application and the concentration of micronutrients in the mushroom highly depends on the planting method and the mineral contents of the compost (Spaulding and Beelman. 2003).

Data in Table 6 show that the interaction of $\mathrm{Fe} \times \mathrm{SF}$ was significant for mushroom carbohydrate content. When no inoculation was performed $\left(\mathrm{B}_{0}\right), \mathrm{SF}_{0}$ outperformed $\mathrm{SF}_{3}$ and $\mathrm{SF}_{1.5}$ significantly whilst in the treatments inoculated with $P$. putida $\left(\mathrm{B}_{1}\right)$, the highest carbohydrate content was obtained from $\mathrm{SF}_{3}$ (Figure 7). The comparison of means for $\mathrm{Fe} \times \mathrm{SF}$ revealed that under no $\mathrm{Fe}$ application $\left(\mathrm{Fe}_{0}\right)$, the different levels of soybean flour did not differ significantly, but when Fe was applied $\left(\mathrm{Fe}_{500}\right)$, the difference between the soybean flour levels was significant, and maximum carbohydrate content was related to $\mathrm{SF}_{3}$ (Figure 8).

Consistent with our findings, Chen et al., (2000), Jurak et al., (2014), and Chang and Wasser (2017) reported a reverse relationship between protein content and mushroom carbohydrate content and concluded that protein-rich supplements have a negligible or reducing impact on the carbohydrate content. But, Zied et al., (2011) disclosed that unlike wheat barn and cottonseed meal, soybean flour increased mushroom carbohydrate and protein contents significantly versus the control and other supplements.

In our study as well, the maximum carbohydrate content was obtained from $\mathrm{SF}_{3}$ when it was applied along with $\mathrm{Fe}$ or $P$. putida, but when $\mathrm{SF}_{3}$ was used alone, no significant increase was observed in carbohydrate content when compared to $\mathrm{SF}_{0}$. Therefore, the results reveal that the enhancement of mushroom carbohydrate content by a supplement like soybean flour requires the cooperation of Fe or P. putida. 


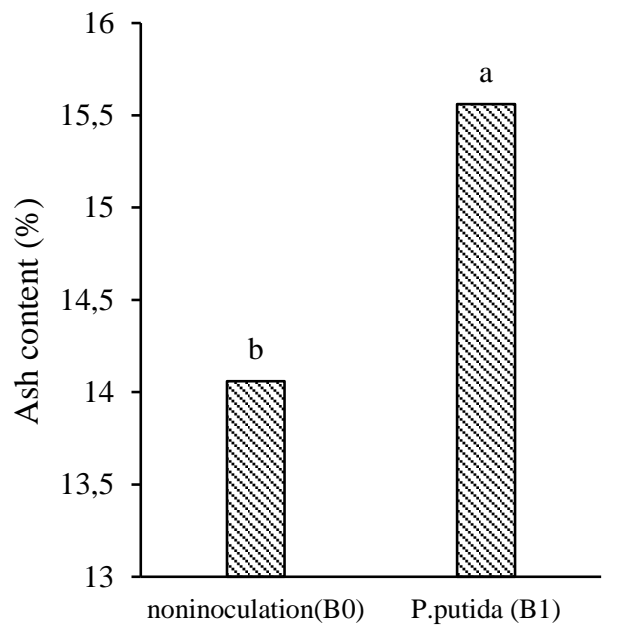

Figure 1. Mean comparison of bacteria main effect on ash content

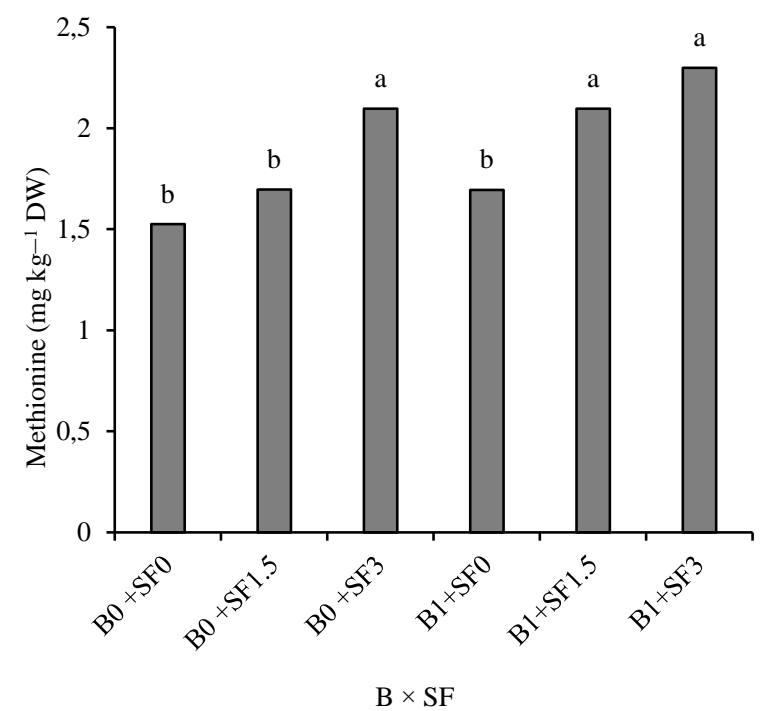

Figure 3. Mean comparison of interaction effect of $\mathrm{SF} \times \mathrm{B}$ on methionine content

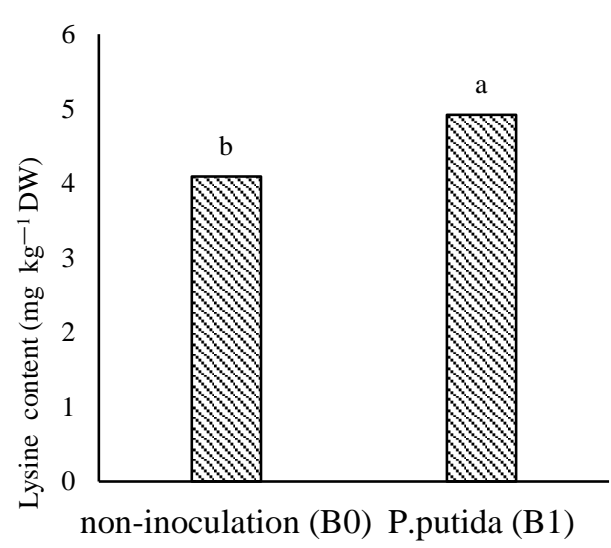

Figure 5. Mean comparison of bacteria main effect on lysine content

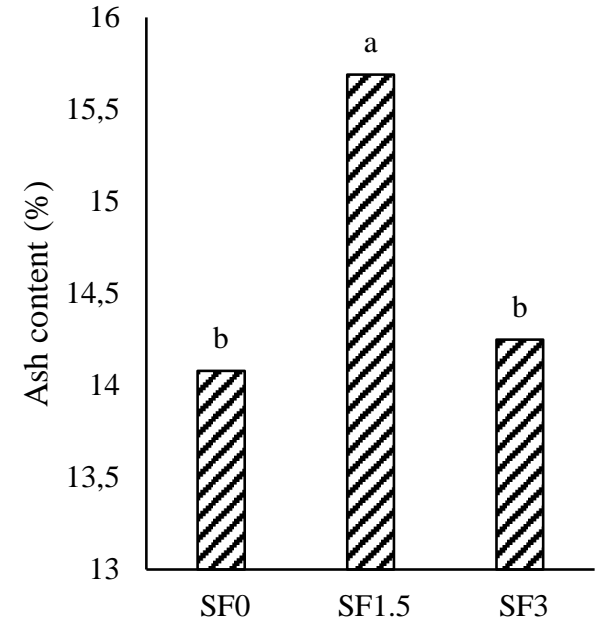

Figure 2. Mean comparison of soy-flour main effect on ash content

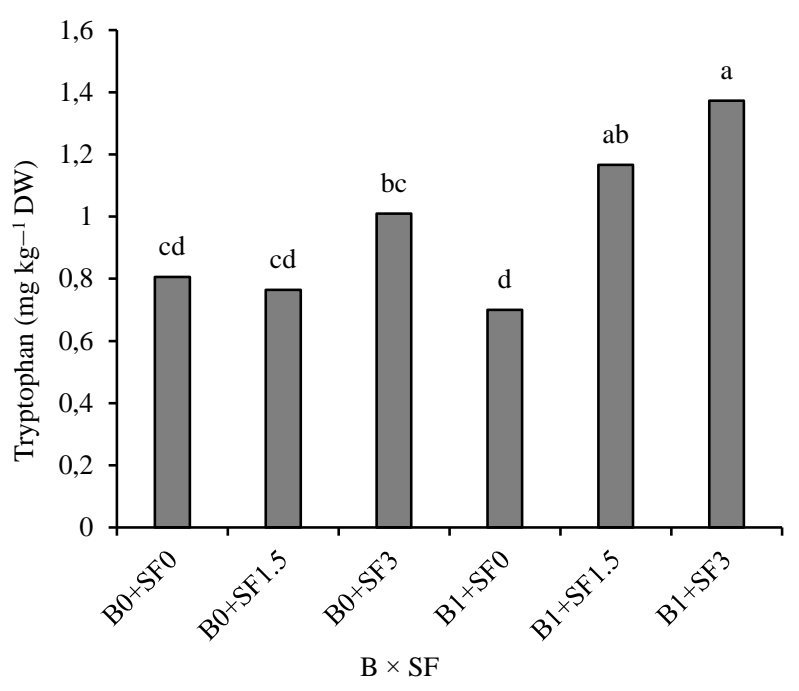

Figure 4. Mean comparison of interaction effect of SF× B on tryptophan content

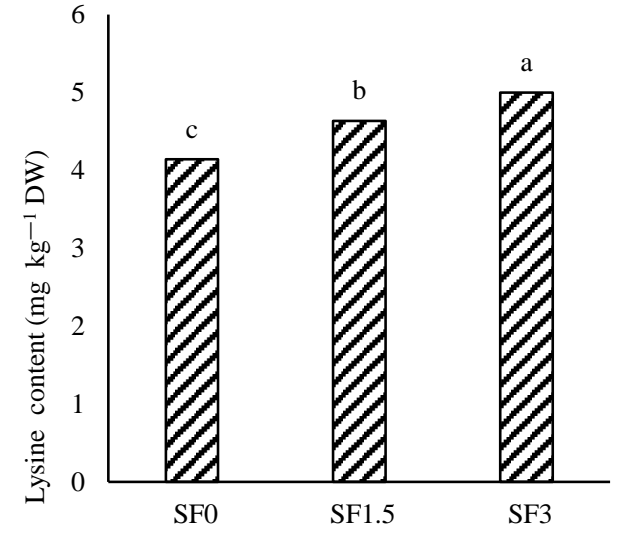

Figure 6. Mean comparison of soy-flour main effect on lysine content 
Antioxidant capacity was affected by the interactions of $\mathrm{B} \times \mathrm{Fe}$ and $\mathrm{B} \times \mathrm{SF}$ (Table 6 ). The comparison of means for $\mathrm{B} \times \mathrm{Fe}$ showed that under both inoculated $\left(\mathrm{B}_{0}\right)$ and non-inoculated $\left(\mathrm{B}_{1}\right)$ conditions, $\mathrm{Fe}_{500}$ had higher antioxidant capacity than $\mathrm{Fe}_{0}$, the only difference being that it was $10.32 \%$ higher in $\mathrm{Fe}_{500}$ than in $\mathrm{Fe}_{0}$ under noninoculated conditions whereas it was $19.44 \%$ higher under inoculated conditions (Figure 9). Based on the comparison of means for $\mathrm{B} \times \mathrm{SF}$, when no inoculation was applied, higher soybean flour rate was related to higher antioxidant capacity so that $\mathrm{FS}_{1.5}$ had $12.8 \%$ higher and $\mathrm{FS}_{3}$ had $22.4 \%$ higher antioxidant capacity than the control, respectively.

In the plots inoculated with $P$. putida, there was not a significant difference between $\mathrm{FS}_{1.5}$ and $\mathrm{FS}_{3}$, but their antioxidant capacities were significantly higher than $\mathrm{FS}_{0}$. It was revealed that the antioxidant capacity in $\mathrm{FS}_{3}$ was increased by $22.4 \%$ in the non-inoculated plots and by $39.8 \%$ in the inoculated plots. (Figure 10). Ebadi et al., (2012) reported that among IAA producing bacteria, ACC deaminase synthesizing bacteria, phosphate solubilizing bacteria, and siderophore producing bacteria, the highest yield was related to the ACC deaminase synthesizing bacteria with $12 \%$ increase in mushroom fresh weight as compared to the control. However, they showed that the highest dry matter level, the most number of mushrooms, and the highest protein content were related to the bacteria that had these features at a moderate level.

Singh et al., (2000), on the other hand, reported that among 34 isolates of Pseudomonas fluorescens in the casing soil, two isolates increased nodule-like structures and the yield of $A$. bisporus significantly and shortened the fruiting part development period by 7 days. These isolates have a biocontrolling effect on different pathogenic fungi and increase yield by controlling their

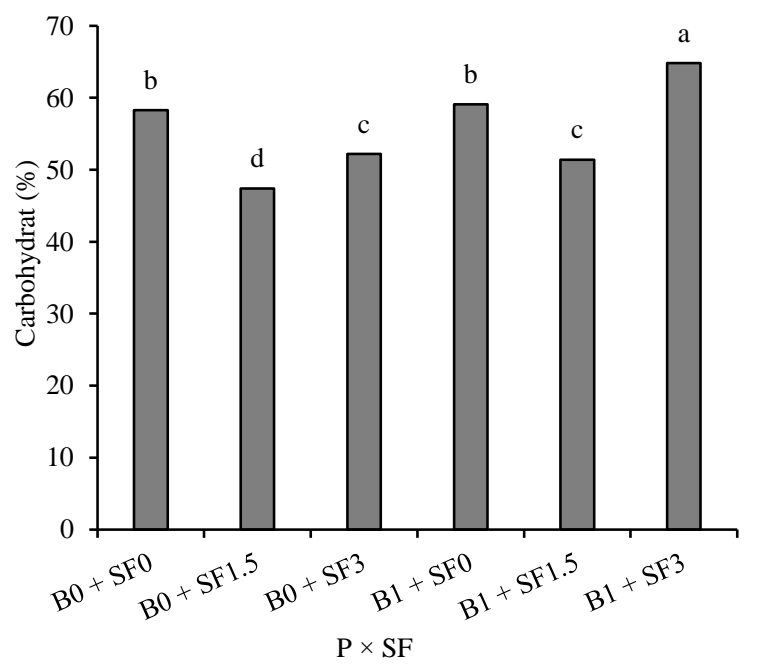

Figure 7. Mean comparison of $\mathrm{P} \times \mathrm{SF}$ on carbohydrate content of mushroom pathogenicity. The difference in results for $A$. bisporus may arise from the difference in physical and chemical characteristics of the applied casing soil and/or the studied mushroom origin. This difference in results for the inoculation with growth-promoting bacteria is mainly attributed to the diversity in plant type and species, soil composition, the presence of indigenous microorganisms, soil moisture, and inadequate understanding of mechanisms by which growthpromoting bacteria influence plant growth. The interaction effect of $\mathrm{B} \times \mathrm{SF}$ was significant on vitamin $\mathrm{C}$ content (Table 6).

Based on the comparison of means for $\mathrm{B} \times \mathrm{SF}$, the application of soybean flour under no inoculation conditions $\left(\mathrm{B}_{0}\right)$ increased vitamin $\mathrm{C}$ content by $28.5 \%$ in $\mathrm{SF}_{1.5}$ and $20.12 \%$ in $\mathrm{SF}_{3}$. Under inoculation with $P$. putida, $\mathrm{SF}_{1.5}$ enhanced vitamin $\mathrm{C}$ content by $15.4 \%$ and $46.2 \%$ versus $\mathrm{B}_{1}+\mathrm{SF}_{0}$ and $\mathrm{B}_{1}+\mathrm{SF}_{3}$, respectively whilst $\mathrm{SF}_{3}$ did not differ from $\mathrm{B}_{1}+\mathrm{SF}_{0}$ significantly although it resulted in $31.3 \%$ higher vitamin $\mathrm{C}$ content than $\mathrm{B}_{0}+\mathrm{SF}_{0}$ (Figure 11). Most studies have reported an increased level of vitamin $\mathrm{C}$ by $21.4 \%$ in mushrooms treated with soybean flour (Golestani et al., 2014; Nurudeen et al., 2014; Carrasco et al., 2018), which is in agreement with our findings. But, this increase reached $46 \%$ when it was accompanied by inoculation with $P$. putida, implying a synergy between bacteria and soybean flour.

Zied et al., (2011) reported synergy between Pseudomonas and organic N sources as well. Mishra et al., (2013) state that ascorbic acid is a powerful secondary antioxidant that reduces the oxidized form of $\alpha$-tocopherol and $\mathrm{N}$ plays a key role in vitamin $\mathrm{C}$ accumulation. The role of microorganisms, e.g. Pseudomonas, in increasing vitamin $\mathrm{C}$ has been reported by Zarenejad et al., (2012) and Siyoum et al., (2015), too.

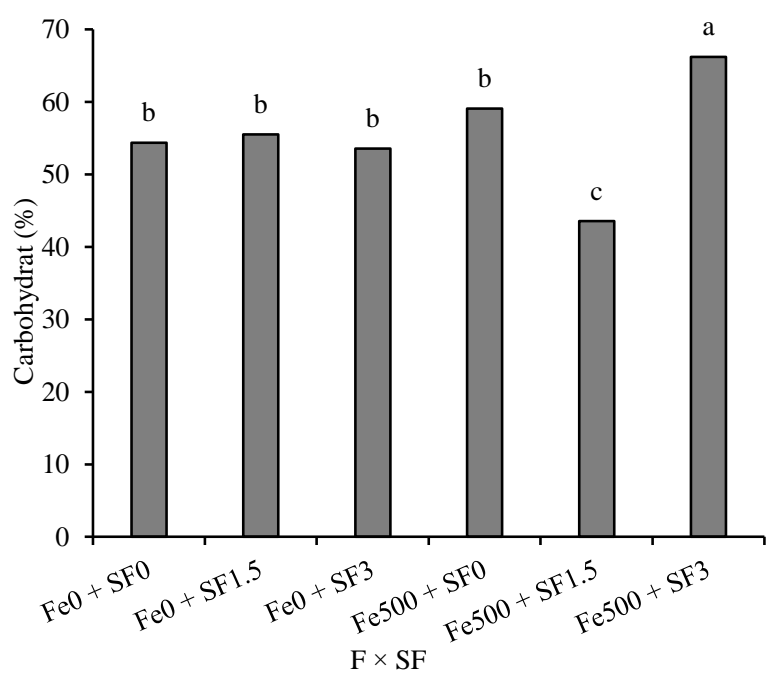

Figure 8. Mean comparison of $\mathrm{F} \times \mathrm{SF}$ on carbohydrate content of mushroom 


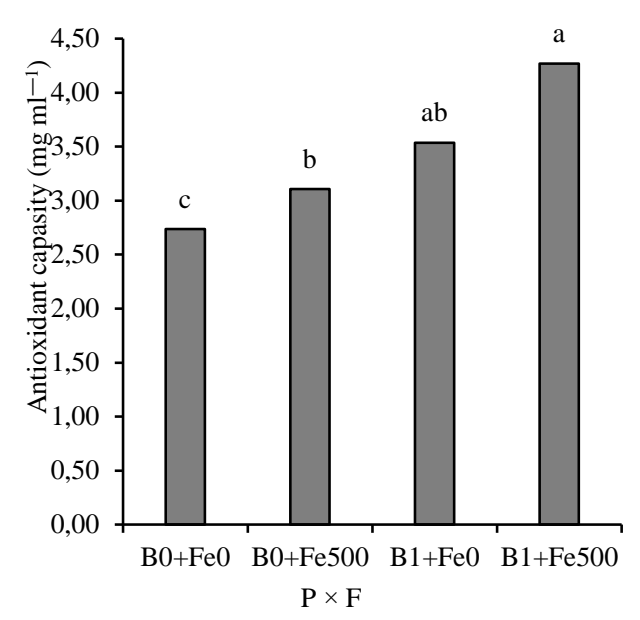

Figure 9. Mean comparison of $\mathrm{P} \times \mathrm{F}$ on total antioxidant capacity of mushroom

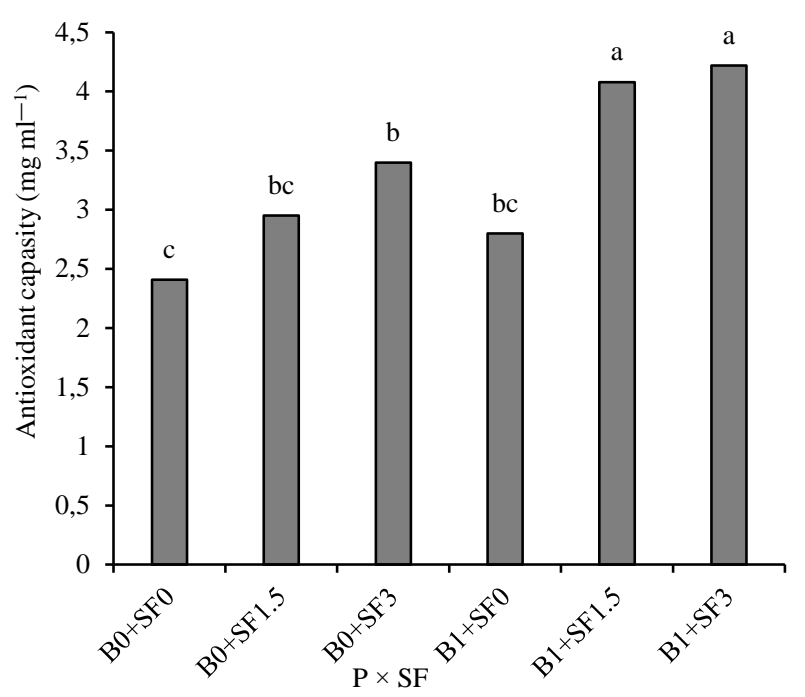

Figure 10. Mean comparison of $\mathrm{P} \times \mathrm{SF}$ on total antioxidant capacity of mushroom

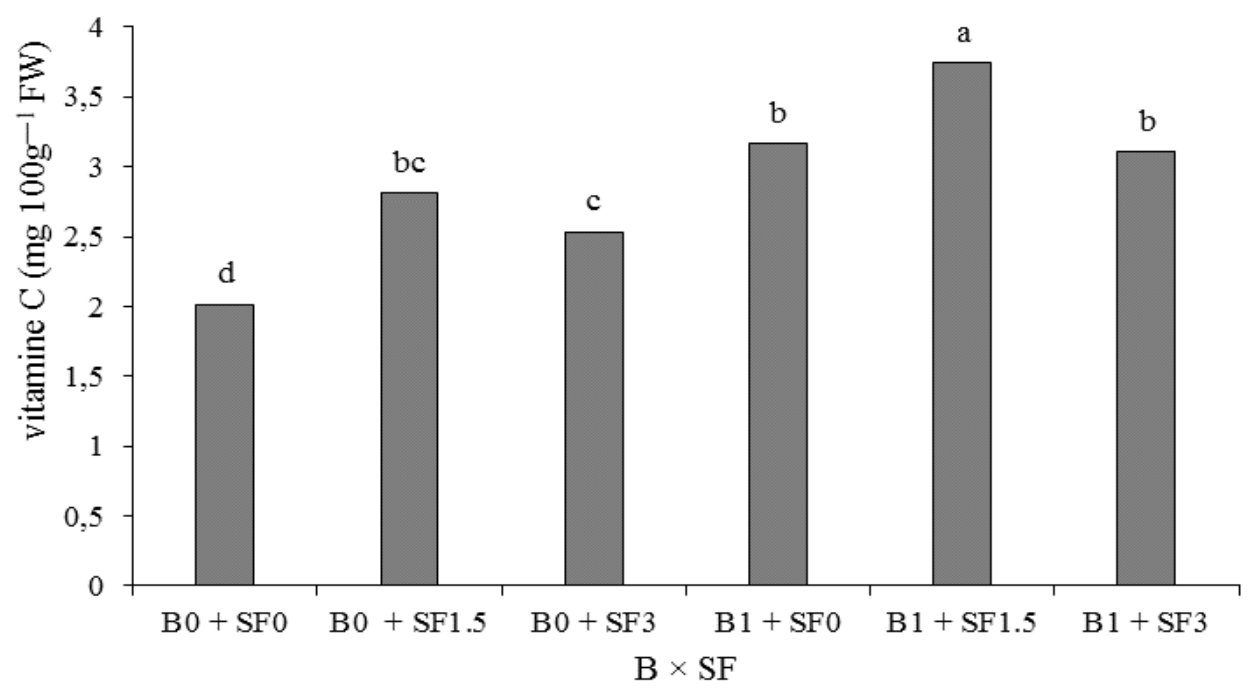

Figure 11. Mean comparison of $\mathrm{P} \times \mathrm{SF}$ on vitamin $\mathrm{C}$ content of mushroom

\section{Conclusions}

In the present work, the interaction effect of soybean flour, iron-chelate, and P. putida, as a source of $\mathrm{N}, \mathrm{Fe}$, and plant growth-promoting bacteria, respectively, were evaluated for improved quality traits and yield of edible mushroom. We found that the application of soybean flour supplement at a rate of $1.5 \%$ of compost dry weight $\left(\mathrm{SF}_{1.5}\right)$ increased most recorded traits, especially dry matter percentage, fresh yield, and biological efficiency when compared to $\mathrm{SF}_{3}$.

The positive effect of $\mathrm{SF}_{1.5}$ was found to be more profound in the presence of $P$. putida so that their synergic relationship was evident in most traits. However, $\mathrm{Fe}$ application $\left(\mathrm{Fe}_{500}\right)$ in the treatments did not differ from their Fe-excluded counterparts in terms of most traits, except for carbohydrate content and antioxidant capacity. The maximum mushroom number, fresh yield, protein, protein yield, biological yield, and vitamin $\mathrm{C}$ were obtained from $\mathrm{SF}_{1.5}+P$. putida. So, to improve yield and qualitative traits of mushrooms, it is recommended to apply $1.5 \%$ soybean flour along with $P$. putida. It is also recommended to address the effect of dual inoculation with $P$. putida-Arbuscular mycorrhiza and different integrated levels of soybean flour and meal on yield and nutrient uptake of edible mushrooms in future studies.

\section{Authors' Contribution}

Abdul Karim Kashi designed and directed this project. Reza Salehi Mohammadi and Fereshteh Makneli performed these experiments. Ahmad Khaliqi and Reza Salehi Mohammadi analyzed the data and interpreted the results. Abdul Karim Kashi and Fereshteh Maknali wrote the manuscript. 


\section{Bibliographic References}

Bonatti, M., Karnopp, P., Soares, H.M., Furlan, S.A. 2004. Evaluation of Pleurotus ostreatus and Pleurotus sajor-caju nutritional characteristics when cultivated in different lignocellulosic wastes. Food Chemistry, 88(3), 425-428. https://doi.org/10.1016/j.foodchem.2004.01.050

Bosch, L.A. Alegri'a, R. Farre'. 2006. Application of the 6aminoquinolyl-N-hydroxysccinimidyl carbamate (AQC) reagent to the RP-HPLC determination of amino acids in infant foods. Journal of Chromatogr, B 831(2), 176-183. https://doi.org/10.1016/j.jchromb.2005.12.002

Carrasco, J., Tello, M.L., De Toro, M., Tkacz, A., Poole, P., Pérez-Clavijo, M., Preston, G. 2019. Casing microbiome dynamics during button mushroom cultivation: implications for dry and wet bubble diseases. Microbiology, 165(6), 611624. https://doi.org/10.1099/mic.0.000792

Carrasco, J., Zied, D.C., Pardo, J.E., Preston, G.M., PardoGiménez, A. 2018. Supplementation in mushroom crops and its impact on yield and quality. AMB Express, 8(1), 1-9. https://doi.org/10.1186/s13568-018-0678-0

Chang, S.T., Wasser, S.P. 2017. The cultivation and environmental impact of mushrooms. In Oxford Research Encyclopedia of Environmental Science, 42(1), 23-37. https://doi.org/10.1093/acrefore/9780199389414.013.231

Chen S., Qiu C., Huang T., Zhou W., Qi Y., Gao Y., Shen J., Qiu L. 2013. Effect of 1-aminocyclopropane-1- carboxylic acid deaminase producing bacteria on the hyphal growth and primordium initiation of Agaricus bisporus. Fungal Ecology, 6(1), 110-118. https://doi.org/10.1016/j.funeco.2012.08.003

Chen, Y., Chefetz, B., Rosario, R., Van Heemst, J.D.H., Romaine, C. P., Hatcher, P. G. 2000. Chemical nature and composition of compost during mushroom growth. Compost Science and Utilization, 8(4), 347-359. https://doi.org/10.1080/1065657X.2000.10702008

Colak, M., Baysal, E., Simsek, H., Toker, H., Yilmaz, F. 2007. Cultivation of Agaricus bisporus on wheat straw and waste tea leaves based composts and locally available casing materials part II: Dry matter, protein and carbohydrate contents of Agaricus bisporus. African Journal of Biotechnology, 6(24), 2855-2859. https://www.ajol.info/index.php/ajb/article/download/58238/465 99. (accessed March 17, 2021)

Colauto, N.B., Fermor, T.R., Eira, A.F., Linde, G.A. 2016. Pseudomonas putida Stimulates Primordia on Agaricus bitorquis. Current Microbiology, 72(4), 482-488. https://doi.org/10.1007/s00284-015-0982-8

Delphina, P.M. Royse, D.J. 2016. The influence of spawn type and strain on yield, size and mushroom solids content of Agaricus bisporus produced on non-composted and spent mushroom compost. Bioresource Technology, 99(8), 32053212. https://doi.org/10.1016/j.biortech.2007.05.073

Desrumaux, B., Calus, A., Sedeyn, P. 2000. Minerals and microelements in the mushroom substrate: A production-limiting factor? Science Cultivation of Edible Fungi, 15(1), 327-334. http://www.fungifun.org/docs/mushrooms/scef2000/scef327. (accessed March 17, 2021)
Ebadi A., Alikhani H.A., Rashtbari M. 2012. Effect of plant growth promoting bacteria (PGPR) on the morphophysiological properties of button mushroom Agaricus bisporus in two different culturing beds.International Research Journal of Basic and Applied Sciences, 3(2), $203-$ 212.

Golestani, T., Hamidoghli, Y., Olfati, J.A. 2014. Substrate, Casing Supplementation and Fragmentation have no Effect on Button Mushroom Yield under Appropriate Conditions. Indian Horticulture Journal, 4 (3 and 4), 162-166. https://doi.org/10.1002/jsfa.5529

Gülser, C., Pekşen, A. 2003. Using tea waste as a new casing material in mushroom (Agaricus bisporus (L.) Sing.) cultivation. Bioresource Technology, 88(2), 153-156. https://doi.org/10.1016/S0960-8524(02)00279-1

Han J, 1999. The influence of photosynthetic bacteria treatments on the crop yield, dry matter content, and protein content of the mushroom Agaricus bisporus. Science Horticulture. 82(1), 171-178. https://doi.org/10.1016/S03044238(99)00043-6

Jiang, T., Zheng, X., Li, J., Ying, T. 2011. Integrated application of nitric oxide and MAP to improve quality retention of button mushroom (Agaricus bisporus). Food $\begin{array}{llll}\text { chemistry, } & 126 & \text { (4), } & 1693-1699 .\end{array}$ https://doi.org/10.1016/j.foodchem.2010.12.060

Jurak, E., Kabel, M.A., Gruppen, H. 2014. Carbohydrate composition of compost during composting and mycelium growth of Agaricus bisporus. Carbohydrate polymers, 101(1), 281-288. https://doi.org/10.1016/j.carbpol.2013.09.050

Kertesz, M.A., Thai, M. 2018. Compost bacteria and fungi that influence growth and development of Agaricus bisporus and other commercial mushrooms. Applied microbiology and biotechnology, 102(4), https://doi.org/10.1007/s00253-018-8777-z

Kim, M.K., Math, R.K., Cho, K.M., Shin, K.J., Kim, J.O., Ryu, J.S., Lee, Y.H., and Yun, H.D. 2008. Effect of pseudomonas sp.p7014 on the growth of edible mushroom pleurotus eryngii in bottle culture for commercial production. Bioresource $\begin{array}{llll}\text { Technology, } & 99 & \text { (1), } & \text { 3306-3308. }\end{array}$ https://doi.org/10.1016/j.biortech.2007.06.039

Kirbag, S., Akyuz M, 2009. Evaluation of agricultural wastes for the cultivation of Pleurotus eryngii (DC. ex Fr.) Quel. var. ferulae Lanzi. African Journal of Biotechnology. 7 (20): 3660-3664.

Klein, B.P., Perry, A.K. 1982. Ascorbic acid and vitamin A activity in selected vegetables from different geographical areas of the United States. Journal of Food Science, 47(2), 941948. https://doi.org/10.1111/j.1365-2621.1982.tb12750.x

Kumar, V., Goala, M., Kumar, P., Singh, J., Kumar, P., Kumari, S. 2020. Integration of treated agro-based wastewaters (TAWs) management with mushroom cultivation. Environmental Degradation: Causes and Remediation Strategies, 6(1), 63-75.

Mamiro, D.P., Royse, D.J. 2008 The influence of spawn type and strain on yield, size and mushroom solids content of Agaricus bisporus produced on non-composted and spent mushroom compost. Bioresource Technology, 99, 3205-3212. https://doi.org/10.1016/j.biortech.2007.05.073 
Mascarin, G.M., Kobori, N.N., Jackson, M.A., Dunlap, C.A., Delalibera Jr, Í. 2018. Nitrogen sources affect productivity, desiccation tolerance and storage stability of Beauveria bassiana blastospores. Journal of applied microbiology, 124(3), 810-820. https://doi.org/10.1111/jam.13694

Mishra, K.K., Pal, R.S., Arunkumar, R., Chandrashekara, C., Jain, S.K., Bhatt, J.C. (2013). Antioxidant properties of different edible mushroom species and increased bioconversion efficiency of Pleurotus eryngii using locally available casing materials. Food Chemistry, 138(2-3), 1557-1563. https://doi.org/10.1016/j.foodchem.2012.12.001

Mohammad A.O., Sabaa A.E. 2013. Impact of some Pseudomonas spp. isolated from casing soil on the hyphal growth of Agaricus bisporus. Canadian Journal on Computing in Mathematics, Natural Sciences, Engineering and Medicine, $4(1), 45-48$.

Nurudeen, T.A., Ekpo, E.N., Olasupo, O.O., Okunrotifa, A.O. Haastrup, N.O. 2014. Effect of Supplements on the Yield and Nutritional Composition of Oyster Mushroom (Pleurotus sajorcaju) Cultivated on Sawdust Forestry. Journal of Environmental Science, 3(4), 1242-1251.

Pardo-Giménez, A., Carrasco, J., Roncero, J.M., Álvarez-Ortí, M., Zied, D.C., Pardo-González, J.E., 2018. Recycling of the biomass waste defatted almond meal as a novel nutritional supplementation for cultivated edible mushrooms. Acta Scientiarum, Agronomy, 40(1), 34-39. https://doi.org/10.4025/actasciagron.v40i1.39341

Prathap, M., Ranjitha Kumari, B.D., 2015. A critical review on plant growth promoting rhizobacteria. Journal of Plant Pathology and Microbiology, 6(4), 1-4. http://www.omicsonline.org/open-acces. (accessed March 17, 2021)

Pratiksha, K., Narute, T.K., Surabhi, S., Ganesh, A., Sujoy, S. 2017. Effect of liquid biofertilizers on the yield of button mushroom. Journal of Mycopathological Research, 55(2), 135141.

Remezan, D., B.A. Siahsar. 2010. Assessing the impact of casing soil on some quantitative and qualitative characteristics of button mushroom (Agaricus bisporus L.). Iranian Journal of Hortcultural Science, 41(3), 393-393 (In Persian). https://dx.doi.org/10.22067/jhorts4.v31i4.62979

Roca, A., Pizarro-Tobías, P., Udaondo, Z., Fernández, M., Matilla, M.A., Molina-Henares, M.A., Molina, L., Segura, A., Duque, A., Ramos, J.L. 2013. Analysis of the plant growthpromoting properties encoded by the genome of the rhizobacterium Pseudomonas putida BIRD1. Environmental Microbiology, 15(4):780-794. https://doi.org/10.1111/14622920.12037

Roise, L., Pont, S., Baptista , P., Freire, C., Vilas-Boas, M. Ferreira, I.C.F.R. 2016. Antioxidant activity of Agaricus sp. mushrooms by chemical, biochemical and electrochemical assays. Food Chemistry, 111(1), 61-66. https://doi.org/10.3389/fchem.2017.00095

Sanchez-Moreno, C., Larrauri, J., Saura-Calixto, F. 1998.
A procedure to measure the antiradical efficiency of polyphenols. Journal of the Science of Food and Agriculture, 76(2), 270-276. https://doi.org/10.1002/(SICI)10970010(199802)76:2<270::AID-JSFA945>3.0.CO;2-9

Schisler, L.C., 1967. Stimulation of yield in the cultivated mushroom by vegetable oils. American Society for Microbiology, 15(4), 844-850. https://aem.asm.org/content/aem/15/4/844.full.pdf. (accessed March 17, 2020)

Sing, R.N., Jain, V.B., 2016. Nutrient supplementation for good yield of button mushroom. Indian Phytopathology, 35(4), 535536.

Singh, M., Singh, R.P., Chaube, H.S., van Griensven, L.J.L.D., 2000. Siderophore producing bacteria as potential biocontrol agents of mushroom diseases. Mushroom Science, 15(2), 577585 .

Siyoum, N.A., Surridge, K., van der Linde E.J., and Korsten, L., 2015. Microbial succession in white button mushroom production systems from compost and casing to a marketable packed product. Annals of Microbiology, 66(1): 151-164. https://doi.org/10.1007/s13213-015-1091-4

Spaulding, T., Beelman, R., 2003. Survey evaluation of selenium \& other minerals in Agarcus mushrooms commercially grown in the United States. Mushroom news, 51(1), 6-9.

Vieira, F.R., Pecchia, J.A., 2018. An exploration into the bacterial community under different pasteurization conditions during substrate preparation (composting phase II) for Agaricus bisporus cultivation. Microbial ecology, 75(2), 318-330. https://doi.org/10.1007/s00248-017-1026-7

Vieyra, F.E, Palazzi, V.I, Pinto, M.S., Borsarelli C.D. 2009, Combined UV-Vis absorbance and fluorescence properties of extracted humic substances-like for characterization of composting evolution of domestic solid wastes. Geoderma, 151(1), 61-67.

https://doi.org/10.1016/j.geoderma.2009.03.006

Wang, D., Sakoda, A., Suzuki, M. 2000. Biological efficiency and nutritional value of Pleurotus ostreatus cultivated on spent Beer grain. Bioresouree Technology, 78 (2), 293-300. https://doi.org/10.1186/s13568-016-0304-y

Weil, D., Beelman, R., Beyer, D. 2006. Manganese and other micronutrient additions to improve yield of Agaricus bisporus.

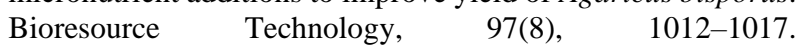
https://doi.org/10.1016/j.biortech.2005.04.042

Zarenejad, F., Yakhchali, B., Rasooli, I. 2012. Evaluation of indigenous potent mushroom growth promoting bacteria (MGPB) on Agaricus bisporus production. World Journal of Microbiology and Biotechnology, 28(1), 99- 104. https://doi.org/10.1007/s11274-011-0796-1

Zied, D.C., Savoie, J.M., Pardo-Giménez, A., 2011. Soybean the main nitrogen $n$ source in cultivation substrates of edible and medicinal mushrooms. Soybean and nutrition, 22(2), 433452. https://doi. org/10.5772/17692 